\title{
Pengembangan Nilai-Nilai Qur'ani Pada Anak Melalui Pembentukan Taman Pendidikan Al-Qur'an (TPQ) Di Desa Naru
}

\author{
${ }^{1}$ Muhammad, ${ }^{2}$ Nurjumiati, ${ }^{3}$ Syahriani Yulianci, ${ }^{3}$ Asriyadin \\ ${ }^{1234}$ STKIP Taman Siswa Bima, \\ Emailyulianci.syah@gmail.com
}

\begin{abstract}
Abstrak. Desa Naru yang berada di kecamatan Woha, kabupaten Bima tidak memiliki TPQ. Sehingga anak-anak yang seharusnya masih diberikan pengajaran tentang agama islam tidak mendapatkan hal tersebut secara maksimal karena kurangnya sarana dan prasarana. Tujuan dari program kemitraan masyarakat ini adalah pengembangan nilai-nilai qur'ani dengan membetuk TPQ di wilayah desa Naru. Moetode pelaksanaan dilakukan dengan Bottom Up, yang artinya perencanaan Tindakan menjawab permasalahn dan kebutuhan masyarakat dilakukan secara partisipatif. Kegiatan terbagi dalam tiga tahap yaitu kegiatan awal yang terdapat sosialisasi dan persiapan, kemudian kegiatan inti, serta kegiatan akhir yaitu evaluasi. Hasil dari pelaksanaan kegiatan di antaranya adalah terbentuknya TPQ yang diberi nama TPQ Al-arsy. Kegiatan pembelajaran dilakukan setiap hari senin sampai dengan jum'at. Materi yang diajarkan antara lain membaca Iqro, praktek wudhu dan sholat, hafalan surat pendek, Bahasa arab, serta maeri-materi agama lainnya. Pendidik di TPQ Al-Arsy berjumlah enam orang, proses pengajaran dilakukan secara bergantian sesuai jadwal. Santri-santri berasal dari desa Naru, berjumlah 35 santri.
\end{abstract}

\section{Kata kunci: Pengembangan Nilai-Nilai Qur'ani; Pembentukan Taman Pendidikan Al-Quar'an}

\section{PENDAHULUAN}

Peraturan pemerintah nomor 55 pasal 24 ayat 1 tahun 2007 tentang Pendidikan agama dan keagamaan menjelaskan bahwa Taman Pendidikan Al-Qur'an adalah sebuah Lembaga Pendidikan keagamaan non formal yang mempunyai tujuan untuk meningkatkan kemampuan peserta didik dalam membaca, menulis, memahami dan mengamalkan kandungan Al-Qur'an (Hakim, 2015). Secara umum TPQ bertujuan untuk menyiapkan santri-santrinya menjadi generasi Qur'ani yakni generasi yang berkomitmen terhadap Al-Qur'an (Siti Khawarin, Rumzi Samin, 2017). TPQ juga bertujuan untuk membiasakan para santri menjadikan AlQur'an sebagai pedoman (Setiawan et al., 2018)

TPQ biasa didirikan langsung di tempat ibadah seperti masjid atau musholah. Desa Naru berada di wilayah Kecamatan Woha, yang terbagi menjadi empat wilayah yaitu dusun kalate, dusun sinar, dusun perintis, dan dusun tani mulya. Di tiap dusun sudah masing-masing memiliki musholah. Mushola dan masjid yang ada hanya digunakan sebagai tempat untuk melaksanakan ibadah sholat. Padahal musholah dan masjid juga dapat digunakan sebagai tempat menuntut ilmu khususnya dalam bidang agama seperti pengadaan TPQ untuk memberikan pemahaman agama pada anak usia dini, selain materi-materi agama yang diperoleh dari sekolahnya.

Di Desa Naru, proses belajar mengaji hanya diperoleh melalui guru ngaji yang melaksanakan proses pengajaran secara individu. Di tiap dusun, memiliki dua guru ngaji yang memiliki SK langsung dari pemerintah desa. Namun ada beberapa guru ngaji yang sudah mendapatkan SK tersebut tetapi tidak melakukan tanggung jawab yang ada atau dapat dikatakan tidak aktif. Sehingga desa Naru kurang memiliki sarana dan prasarana untuk memberikan pemahaman lebih tentang Pendidikan agama di usia dini.

Guru ngaji sangat di butuhkan di tiap wilayah tersebut karena dapat memberikan pengajaran Al-Qur'an kepada anak-anak melihat banyaknya anak-anak yang masih duduk di sekolah dasar. Kegiatan mengaji biasa dilakukan pada malam hari yaitu setelah magrib. Hal ini membuat anak-anak di malam hari tidak bisa belajar secara maksimal mengingat waktu yang akan semakin larut malam. Sedangkan pada sore hari anak-anak 
bermain di lingkungan sekitarnya. Pada sore hari mushola terlihat sepi dari kegiatan keagamaan. Seperti yang ditunjukan pada Gambar 1 dan Gambar 2.

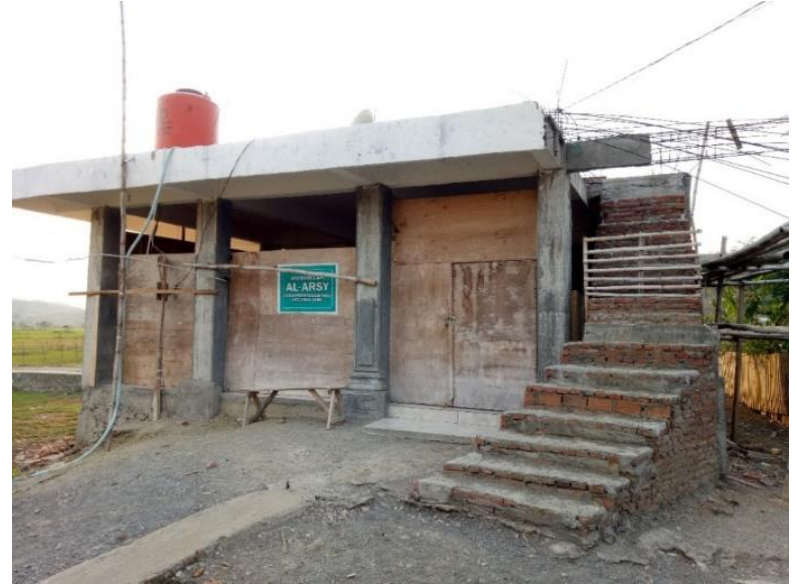

Gambar 1. Mushola Al-Arsy Dusun Tani Mulya

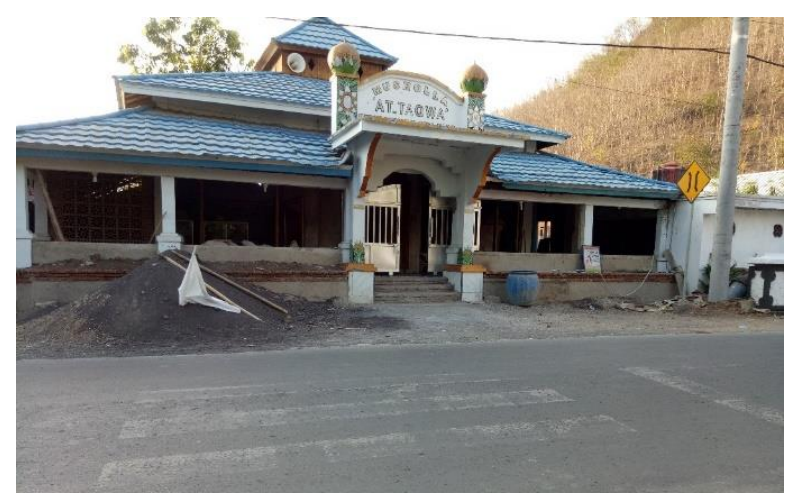

Gambar 2. Musholla At-Taqwa di Dusun Perintis

Orang tua sebagai pemimpin dalam keluarga mempunyai peran yang sangat besar bagi pengembangan anak baik perilaku maupun keterampilan hidup (Anisah, 2011)(Rakhmawati, 2015). Namun dalam pengembangannya saat ini karena berbagai kesibukkan dan permasalahan yang dihadapi orang tua, ada kecenderungan bahwa pendidikan terutama mengenai pendidikan agama hanya diserahkan pada sekolahnya saja.

Selain itu, motivasi dari orang tua juga sangat diperlukan dalam hal untuk mendorong serta mendukung anaknya belajar agama di luar sekolah (Noor Komari Pratiwi, 2015). Namun sayangnya motivasi dari orang tua masih sangat kurang. Alasan dari beberapa orang tua yang diwawancara adalah tidak adanya sarana dan prasarana yang mendukung, anak-anak pada sore hari lebih suka bermain dibandingkan belajar karena di waktu pagi mereka sudah disibukkan dengan kegiatan sekolah seperti yang terlihat pada Gambar 3.

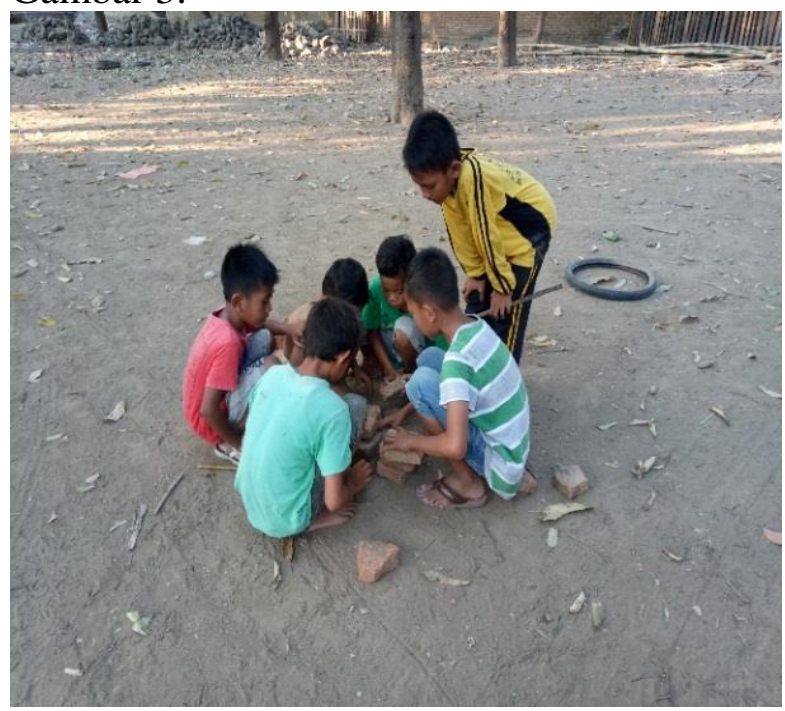

Gambar 3. Potret umum Kegiatan anak di sore hari

\section{METODE PELAKSANAAN}

Pada pelakasaaan kegiatan Pengabdian Kepada Masyarakat (PKM) ini yang menjadi target kegiatan adalah anak-anak yang masih duduk dibangku Sekolah Dasar. Kegiatan ini bekerjasama dengan Mitra Pemerintahan desa Naru. Pendekatan yang dilakukan bersifat Bottom Up. Bottom Up adalah perencanaan tindakan menjawab permasalahan dan kebutuhan masyarakat dilakukan secara partisipatif (Henry, 2014).

\section{HASIL DAN PEMBAHASAN (12pt)}

a. Kegiatan Awal :

1) Sosialisasi: bertujuan untuk memberikan informassi dan motivasi kepada Mitra khususnya orang tua wali murid agar dapat memotivasi dan memberiakan dukungan pada anakanaknya.

2) Persiapan: bertujuan untuk mengindetifikasi dan menyiapkan segala kebutuhan untuk pelaksanaan kegiatan, kegiatan persiapan dilakukan secara bersama dengan melibatkan Mitra dan orang tua murid untuk menyusun jadwal kegiatan (waktu, lokasi, dan susunan kegiatan).

b. Kegiatan Inti: Pembentukan Taman Pendidikan Al-Qur'an. 


\section{Taman Pendidikan Al-Qur'an} merupakan bentuk kegiatan yang akan rutin dilaksanakan oleh Musholah Al-Arsy setiap sore hari Senin, Selasa, dan Rabu. Kegiatan ini dijadikan sebagai sarana menanamkan nilai-nilai Qur'ani melalui keterampilan dalam menulis, membaca, serta mengamalkan Al-Qur'an dalam kehidupan sehari-hari.

1) Dilaksanakan secara rutin 3 kali seminggu di Musholah Ar-Arsy pukul 16.00-17.30 WITA.

2) Staf pengajar: Pemuda sekitar yang ahli dalam pengajaran Al-Qur'an serta tokoh agama yang ada di lingkungan sekitar.

c. Evaluasi: Dilakukan untuk mengetahui pencapaian tujuan pembentukan TPQ. Evaluasi kegiatan ini menggunakan instrument angket, observasi dan wawancara. Angket digunakan untuk mengetahui respon orang tua murid terhadap pembentukan TPQ. Instrumen angket juga digunakan untuk mengetahui nilai-nilai Qur'ani terhadap peserta didik setelah melakanakan kegiatan yang ada di TPQ. Observasi digunakan untuk mengamati kemampuan membaca, menulis serta pengamalan nilai-nilai Qur'ani dalam kehidupan, dan wawancara digunakan untuk mendukung data evaluasi lainnya.

Berdasarkan tabel tersebut dijelaskan bahwa program kegiatan TPQ al-Arsy berjalan dengan lancar. Pelaksanaan kegiatan pembelajaran telah sesuai dengan apa yang direncanakan dan dipersiapkan sebelumnya. Kegiatan pembelajaran TPQ Al-Arsy dilakukan setiap hari senin samapai dengan jum'at. Hal tersebut sesuai dengan jadawal yng disepakati. Materi yang diajakan meruapakan materi yang telah di sepakati bersama dengan pihak TPQ dan pihak pengabdian. Salah satu ustadz menerangkan dalam proses pembelajaran di TPQ Al-Arsy dikelompokkan menjadi 2 yakni kelas santri putra dan kelas santri putri.

Tepat pukul 16.00 WITA para santri mulai berdatangan satu persatu sambil menunggu ustadz dan ustazah hadir para santri memperoleh jadwal piket kebersihan, langsung membersihkan dan menyiapkan keperluan proses pembelajaraan. Setelah lokasi pemeblajaran bersih serta para santri, ustadz dan ustadzah telah hadir. Salah satu Ustadz mengintruksi para santri untuk berkumpul sesuai dengan kelompoknya masing-masing.

Dalam proses pembelajaran membaca iqro' ustadz dan ustadzah akan memanggil satu persatu santri. Santri yang dipanggil akan maju kemudian ustad akan memerintahkan membuka halaman sesuai dengan kartu belajar santri. Dalam proses pembelajaran ustad dan ustadzah memberikan penjelasan awal mengenai materi yang akan dibaca oleh santri sehingga santri memahami ketentuan dan cara membaca basmalah dilanjutkan membaca iqro'. Setelah memebaca iqro' santri diwajibkan untuk menulis halaman iqro' yang akan dibaca untuk pertemuan selanjutnya. Dalam proses pemebelajaran terdapat 2 evaluasi, evaluasi harian yang dilaksanakan ketika santri membaca masingmasing halaman dan evaluasi per tiga bulan yang akan disosialisasikan ke orang tua santri.

Kegiatan pembelajaran yang dilaksanakan di TPQ Al-Arsy tidak hanya membaca iqro', ada beberapa kegiatan pemebelajaran yang di terapkan TPQ al-Arsy antara lain wudhu, sholat, hafalan surat pendek, Bahasa Arab. Belajar berwudhu dilakukan setiap pertemuan, wudhu dilakukan sebelum memulai kegiatan di TPQ, ustad dan ustadzah bersama-sama dengan santri mempraktekkan wudhu yang benar dan mengajar doa sebelum dan setelah wudhu. Ustadz memberikan pembelajaran praktek gerakan sholat dan bacaan sholat, kegiatan pembelajaran ini dilaksnakan setiap hari setiap kamis sore.

Kegiatan pembelelajaran selanjutnya adalah menghafal surat-surat pendek pada santri. pada kesempatan ini pembelajaran hafalan adalah menghafal surat Al-Fatihah, Al-Ikhlas, Annas, Al-Falaq, materi hafalan bukan hanya untuk menghafal surat-surat pendek tetapi juga untuk menghafal do'a sehari-sehari dan berhitung menggunkan bahasa arab dengan metode bernyanyi. Santri diminta untuk membaca bersama-sama, kegiatan ini dilaksanakan setiap Jum'at sore.

Terdapat beberapa faktor yang dapat mempengaruhi motivasi anak dalam belajar 
agama. Di antaranya adalah dari kedua orang tua dan lingkungan(Subianto, 2013). Apabila orang tua paham dengan tujuan dari pengajaran agama, maka orang tua itupun mampu menjelaskan dan meyakini anakanaknya dengan baik. Peran orang tua tidak dapat dihilangkan dari Pendidikan agama seorang anak (Yuhana \& Aminy, 2019)(Fattah, 2017). Karena orang tua merupakan pengambil keputusan sepenuhnya terhadap pendidikan anak. Di desa Naru, kritik dan saran dari orang tua santri selama proses pembentukan TPQ, tetap selalu dipertimbangkan dan dapat dijadikan sebagai bahan evaluasi.

\section{KESIMPULAN}

Tujuan dari pelaksanaan kegiatan ini adalah untuk membentuk nilai-nilai Qur'ani melalui pembentukan TPQ di desa Naru. Kesimpulan dari pelaksanaan kegiatan pengabdian kepada masyarakat ini adalah nilai-nilai qur'ani santri mampu dibentuk. Materi-materi yang diperoleh mampu membuat santri mengimplementasikan teoriteori yang telah diajarkan.

\section{UCAPAN TERIMA KASIH}

Ucapan terima kasih ditujukan pada LPPM STKIP Taman Siswa Bima yang telah mendanai kegiatan Pengabdian Kemitraan Masyarakat (PKM) internal Tahun Anggaran 2020.

\section{DAFTAR PUSTAKA}

Anisah. (2011). Pola Asuh Orang Tua Dan Implikasinya Terhadap Pembentukan Karakter Anak. Jurnal Pendidikan Universitas Garut, 5(1), 70-84.

Fattah, A. (2017). Konsep Pendidikan Karakter Dalam Perspektif Hadits. TARBAWI: Jurnal Pendidikan Agama Islam, 1(2), 113-122. https://doi.org/10.26618/jtw.v1i2.364

Hakim, R. (2015). Pembentukan Karakter Peserta Didik Melalui Pendidikan Berbasis Al-Quran. Jurnal Pendidikan Karakter, O(2), 123-136. https://doi.org/10.21831/jpk.v0i2.2788

Henry. (2014). Partisipasi Masyarakat Dalam Perencanaan Pembangunan (Studi Kasus
Pada Kecamatan Sidikalang Kabupaten Dairi). Jurnal Administrasi Publik, Volume 2(Desember 2014), 118.

Noor Komari Pratiwi. (2015). Pengaruh Tingkat Pendidikan, Perhatian Orang Tua, dan Minat Belajar Siswa Terhadap Prestasi Belajar Bahasa Indonesia Siswa SMK Kesehatan di Kota Tangerang Noor. Jurnal Pujangga, Vol. 1(No 2), 75-105.

Rakhmawati, I. (2015). Peran Keluarga dalam Pengasuhan Anak. Jurnalbimbingan Konseling Isla, 6(1), 1-18. https://doi.org/10.21043/kr.v6i1.1037

Setiawan, D., Rusdi, A., \& Putri, V. A. (2018). Peran TPA dalam Penyelenggaraan Pendidikan Al-Qur'an di Masjid Al-Fattah Palembang. JIP: Jurnal Ilmiah PGMI, 3(2), 170-184. https://doi.org/10.19109/jip.v3i2.1650

Siti Khawarin, Rumzi Samin, I. Y. P. (2017). Implementasi Kebijakan Penuntasan Buta Aksara Al-Qur'an (Studi di Kecamatan Meral Barat Kabupaten Karimun). 1-14.

Subianto, J. (2013). Peran Keluarga, Sekolah, Dan Masyarakat Dalam Pembentukan Karakter Berkualitas. Edukasia: Jurnal Penelitian Pendidikan Islam, 8(2), 331354. https://doi.org/10.21043/edukasia.v8i2.7 57

Yuhana, A. N., \& Aminy, F. A. (2019). Optimalisasi Peran Guru Pendidikan Agama Islam Sebagai Konselor dalam Mengatasi Masalah Belajar Siswa. Jurnal Penelitian Pendidikan Islam, 7(1), 79. https://doi.org/10.36667/jppi.v7i1.357 